\title{
The Relationship Between Training and Career Management on Affective Commitment
}

\author{
Firdaus Bashir ${ }^{1}$, Santhi. $\mathrm{V}^{2}$ \\ firdaussudheer@gmail.com ${ }^{1}$, hod.hum@psgtech.ac.in ${ }^{2}$ \\ Research Scholar, Department of Management Science, PSG College of Technology, Coimbatore, \\ Tamilnadu ${ }^{1}$, Head of the Department, Department of Humanities, PSG College of Technology, \\ Coimbatore, Tamilnadu ${ }^{2}$
}

\begin{abstract}
The degree to which an employee is invested in his or her firm is revealed by organizational commitment. In the realm of HRM, it is an important work-related attitude. Building a devoted workforce requires time and effort, but with the appropriate training and career management, it is possible. This study looks at the impact of training and career management on affective organizational commitment. For the present study affective commitment which is essential to retain in an organisation is taken into consideration.
\end{abstract}

Keywords: HRM practices, training, career management, affective commitment.

\section{Introduction}

High-spirited, competent, and dedicated human assets are necessary to continually drive the organisation to succeed in today's dynamic and competitive market. This demands a Human Resource Management System that balances employee development with company growth. These HRM processes determine if a person is likely to depart his or her work or is willing to stay for an extended period(Brown \& Peterson, 1993). In the future, the HRM idea of reciprocal growth for both the organisation and its members will remain the gold standard. Organisational commitment produces a strong desire to stay in the company by embracing and trusting the firm's value system and putting in the effort required to support overall organisational growth. Training and career management are important elements that boost emotional connection to an organisation. On the surface, these practices are the most essential contemporary human resource management functions that assist employees to develop considerably in their professions.

Career management assists people in defining their career goals and committing to actions and tactics that will help them accomplish them. However, training aids in the learning and development of skill sets, technical knowledge, job-related information, and attitudes. As a consequence, each employee's work productivity rises, as does their commitment to the company. Training bridges the gap between education and employment. Employees are always seeking ways to develop in their careers, and when those probabilities become rare inside a firm, internal employee mobility becomes prevalent. This has a substantial influence on the employer since it accounts for a loss of talent as well as the company's capacity to create a pool of committed employees. 
Training may help enhance knowledge, skill sets, and attitudes toward work-related tasks. It is one of the most powerful motivators for both individuals and organisations, with both short- and long-term benefits. The study's specific objectives are to investigate the relationship between training and affective communication in terms of organisational commitment.

\section{Review of Literature}

Human resource management practices, according to Meyer and Allen (1997), may be utilised to develop commitment. Professional growth was identified as one of the primary subcategories of strategies used by managers to increase employee loyalty by preserving or reestablishing the potential of advancement inside the company. Normative commitment refers to an employee's sense of responsibility to his or her employer because he or she feels it is just and fair to remain with the firm. Because he may be afraid of messing up on benefits he received while working, an individual's continuous commitment permits him to stay with his company.After examining the degree of commitment demonstrated by nurses working in Saudi Arabian public hospitals,

Heru Santoso Wahito Nugroho (2020) discovered that organisational commitment is primarily described by organisational variables such as training and development, organisational support, mentorship, and the type of leadership that exists. It's essential to understand the organisational elements that enhance member loyalty while concentrating on overall quality improvement.Training not only promotes commitment but also offers several other benefits.

Staff training advantages were divided into three categories by Noe and Wilk (1993), Personal benefits: Training may help you build a strong network, boost your job performance, and advance professionally, secondlycareer privileges: these benefits lead to the discovery of new opportunities and career paths, and finally job-related benefits: better relationships with peers and superiors are developed, which may not be possible in a traditional workplace.

Among the numerous functional activities involved in imparting a training programme, the important components highlighted are

1) executing the required training programme,

2) recognising current needs,

3) selecting the appropriate approach,

4) charting a strategy, and

5) finally analysing the training outcomes, as per McCourt \& Eldridge (2003).

Kenneth R. Bartlett (2001) studied the relationship between workers' attitudes about training and their level of organisational commitment by gathering data from 337 nurses. Nurses' perceptions of training improve and they remain interested in their jobs when they think they have easy access to training, social support, and incentives to take up and benefit from the training that is offered.

Kamarul Zaman Ahmad and Raida Abu Bakar (2003) investigated the influence of personnel views on commitment. According to the study, access to training increased affective commitment, whereas the value provided by training appeared to be linked to affective, normative, and continuation commitment. An organization's activities may be shut down if its strategies are poorly articulated, so human resource policies that allow for training and development, recruiting the right person for the right role, increasing organisational commitment, identifying weaknesses, and improving performance are essential. 
According to Sweta Singh (2018), an organization's career management may enhance employee happiness, lower the probability of quitting, and create a better work environment. Employees that have a supportive career plan are more likely to stay with the firm. Employees may leave to explore similar chances elsewhere if a firm fails to manage its internal career trends. According to Mohammed S. Alamri, Thamir I. Al-Duhaim(2017) Commitment can thus be boosted by a good training approach.

\section{Conclusion}

While affective commitment was utilised as a dependent variable in this study, researchers may use a similar study to incorporate other components such as normative and continuous commitment. To have a better understanding, future research might look into the greater articulation of various HRM approaches utilised in organisations. Respondents' career demands vary based on their age and years of experience; such issues might be ideal for future investigation in combination with emotional commitment. After evaluating the impact of training and career management on organisational commitment, the conceptual study found that fundamental human resource management strategies such as training and career management have an impact on organisational commitment. The rate of absenteeism and intention to resign will be reduced as a result of this integration, while the desire to offer the best of one's self to the company will increase, assuring excellent outputs. Workers will create a feeling of attachment to their workplace if need-based training is incorporated. Managing employees' careers by providing them with greater chances will help them build a sense of attachment to their workstation.

\section{References}

[1] Steven P. Brown, Robert A. Peterson (1993). 'Antecedents and consequences of salesperson job satisfaction: Meta-Analysis and assessment of causal effects.' Journal of Marketing Research, Vol 30,1,63-77.

[2] Heru Santoso WahitoNugroho(2020) "Assessment of Organizational Commitment Among Nurses in a Major Public Hospital in Saudi Arabia." Journal of MultidisciplinaryVol 13,607-608.

[3] Kamarul Zaman Ahmad and Raida Abu Bakar., (2003)' The association between trainingand organizational commitment amongwhite-collar workers in Malaysia.'International Journal of Training and Development', Vol 7,3,166-185.

[4] Kenneth R. Bartlett., (2001) 'The Relationship Between Training and Organizational Commitment: A Study in the Health Care Field.' Human Resource Development Quarterly', Vol12,4,335-352.

[5] William McCourt,Willy McCourt and Derek Eldridge (2003)' Global Human Resource Management: Managing People in Developing and Transitional Countries.' Cheltenham, UK: Edward ElgarPublishing Ltd, 2003.

[6] John P. Meyer, P andNatalie J. Allen, N. J. (1997). Commitment in the workplace:Theory, Research and Application, Sage Publications.

[7] Mohammed S. Alamri\& Thamir and Al-Duhaim (2017).' Employees Perception of Training and Its Relationship with Organizational Commitment among the Employees Working at Saudi Industrial Development Fund.' International Journal of Business Administration, Vol. 8, No. 2; 2017

[8] NoeR. A. and Wilk S. L. (1993), 'Investigation of the factors that influence employee's participation in development activities.' Journal of Applied Psychology, Vol 78, 2, 291-302. 
[9] Sweta Singh (2018) 'Organisational career management practices, career satisfaction and intention to quiet among Indian employees: Examining the moderate effect of 'four type of work experience.' Australian council for educational research ,27,3,150-159. 